\title{
Subglottic Cancer Pathologic Distant Metastasis TNM Finding v6
}

National Cancer Institute

\section{Source}

National Cancer Institute. Subglottic Cancer Pathologic Distant Metastasis TNM Finding v6. NCl Thesaurus. Code C64730.

A pathologic finding about one or more characteristics of subglottic cancer, following the rules of the TNM AJCC v6 classification system as they pertain to distant metastases. 